PAPERS READ AT THE ANNUAL SCIENTIFIC MEETING OF THE INTERNATIONAL MEDICAL SOCIETY OF PARAPLEGIA HELD AT STOKE MANDEVILLE, AYLESBURY, ENGLAND, JULY, I98I

SESSION ON SOCIAL EVALUATION OF PARAPLEGICS

\title{
SOCIAL AND VOCATIONAL REINTEGRATION OF PARAPLEGIC AND TETRAPLEGIC PATIENTS IN SWITZERLAND
}

\author{
By F. Jenik, M.D., W. Kunn, N.D., M.D.D. and G. A. ZACH, M.D. \\ Swiss Paraplegic Centre, Im Burgfelderhof 40, CH-4055 Basle, Switzerland
}

Abstract. A review of social and vocational reintegration statistics of 90 spinal cord injury patients admitted in 1979 is presented.

Key words: Paraplegics and tetraplegics; Social conditions; Vocational reintegration.

\section{Introduction}

THE purpose of this statistical review (based on I 18 acute spinal cord injury (SCI) admissions into the Swiss Paraplegic Centre, Basle in 1979), is to give, in the form of an evaluation, consideration to the social and vocational significance of the patients' disability.

\section{Patients}

Out of the total of I 8 patients we could only evaluate 90 because three died, some others did not appear for review or left the country (foreign workers), and some had only questionable transient neurological disturbances. These patients as well as the non-traumatic paraplegics were excluded from the study. The review is small but seems to be representative for the Swiss conditions for recent years when we compare several of its parameters with our annual house-statistics from I974 to 1978 .

Age of 90 evaluated patients (Table I). The decade of the young age-group (15-25 years) is represented by 35.5 per cent and this percentage is equal to that of the next two decades (26-45 years), both groups together making 70 per cent. Among the young people of 25 and below the ratio male to female patients is almost I:I.

TABLE I

Age of 90 evaluated SCI patients (I979)

\begin{tabular}{|c|c|c|c|c|}
\hline yrs & $\mathrm{N}$ & 0 & M & $\mathrm{F}$ \\
\hline I 5-25 & 32 & $35 \cdot 5$ & I 8 & I 4 \\
\hline $26-45$ & 32 & $35 \cdot 5$ & 24 & 8 \\
\hline $46-65$ & 22 & $24 \cdot 5$ & I5 & 7 \\
\hline over 65 & 4 & $4 \cdot 5$ & 3 & I \\
\hline Total & 90 & $100^{0}:$ & 60 & $30(2: I)$ \\
\hline
\end{tabular}


The final ratio is, however, $2: \mathrm{I}$. Table II shows the level and degree of paralysis. The tetraplegic to paraplegic ratio remained approximately 40 to 60 per cent and similar to that of previous years. Twelve $(34.3$ per cent) out of 35 tetraplegics and $25(45.5$ per cent) out of 55 paraplegics remained complete. Forty-five per cent of the patients are now more or less wheelchair dependent.

Vocational guidance and retraining (Table III) were considered as early as possible during the stay at the Paraplegic Centre. In all 70 patients $(77 \cdot 8$ per cent), are or will be (after retraining and reintegration), working, only one being in a sheltered workshop. Out of these 70 patients 25 are tetraplegics (i.e. $7 \mathrm{I} \cdot 5$ per cent of all tetra) and 45 are paraplegics (8I.8 per cent of paraplegics).

TABLE II

Level and degree of paralysis

\begin{tabular}{|c|c|c|c|c|c|}
\hline & below & complete & incomplete & total & $\%$ \\
\hline Tetraplegic & $\begin{array}{l}\mathrm{C}_{4} \\
\mathrm{C} 5 \\
\mathrm{C} 6 \\
\mathrm{C} 7(8)\end{array}$ & $\left.\begin{array}{l}\text { I } \\
5 \\
3 \\
3\end{array}\right\}$ I2 & $\left.\begin{array}{r}2 \\
12 \\
7 \\
2\end{array}\right\} 23$ & $\left.\begin{array}{r}3 \\
17 \\
10 \\
5\end{array}\right\} 35$ & $38 \cdot 8$ \\
\hline Paraplegic & $\begin{array}{l}\text { TI-7 } \\
\text { T8-I2 } \\
\mathrm{LI}\end{array}$ & $\left.\begin{array}{r|r}9 \\
14 \\
2\end{array}\right) 25$ & $\left.\begin{array}{r}\text { I } \\
\text { I } \\
\text { I } 8\end{array}\right) 30$ & $\left.\begin{array}{l}10 \\
25 \\
20\end{array}\right) 55$ & $6 I \cdot 2$ \\
\hline Total & & 37 & 53 & 90 & \\
\hline Percentage & & $4 \mathrm{I}$ & 59 & & 100 \\
\hline
\end{tabular}

TABLE III

Vocational reintegration review

\begin{tabular}{lcccc}
\hline $\begin{array}{l}\text { Lesion } \\
\text { below }\end{array}$ & $\begin{array}{c}\text { Full- } \\
\text { time }\end{array}$ & $\begin{array}{c}\text { Part- } \\
\text { time }\end{array}$ & $\begin{array}{c}\text { Not } \\
\text { working }\end{array}$ & Total \\
\hline C4-8: complete & 0 & 6 & 6 & I2 \\
incomplete & 6 & I3 & 4 & 23 \\
TI-7: complete \\
incomplete & 0 & 5 & 4 & 9 \\
T8-I2: complete & 0 & I & 0 & I \\
$\begin{array}{c}\text { incomplete } \\
\text { Li (cauda-conus, all } \\
\text { but 2 incomplete) }\end{array}$ & 0 & I2 & 2 & I4 \\
Total & 4 & 7 & 2 & II \\
Percentage & I2 & 58 & 20 & 90 \\
\hline
\end{tabular}


Table IV shows the reasons for failure of vocational integration of 20 patients. These were the age (IO), psychological and psychiatric problems (+age) (6) and the severity of the SC-lesion with concomitant other medical problems (4). Some foreign workers (Io per cent of our study), particularly those from Southern Europe, are difficult to reintegrate vocationally because of different social attitudes, language problems and low level of basic education. Moreover, if they have a reasonable chance of achieving a good insurance pension or disability compensation, they tend to aggravate their problems.

On the other hand we ought to aim at presenting patients from suffering financial loss by attempting to work in a badly paid part-time job due to our insurance system.

Table $\mathrm{V}$ concerning car driving shows that out of 35 tetraplegics $\mathrm{I} 7$ ( 48.6 per cent), and out of 55 paraplegics 44 ( $8 \mathrm{I} \cdot 8$ per cent), became car drivers (6I patients67.8 per cent). The causes of inability to drive are listed in the same table.

Marital status. Forty per cent were single, Io per cent engaged, 44.4 per cent married and 5.6 per cent divorced or separated.

Only among the singles have there been post-injury changes in so far as some of them lost their friends (partners without marriage); they also had difficulty in

\section{TABLE IV}

Reasons for vocational non-integration of $20 \mathrm{pts}$

Io pts. (II $1 \%$ ) near or in retirement

6 pts. $(6 \cdot 7 \%)$ due to psychiatric conditions (plus age)

4 pts. $(4 \cdot 4 \%)$ due to severity of SCI and other medical problems

20 pts. $22 \cdot 2 \%$

TABLE V

Car driving

\begin{tabular}{|c|c|c|c|}
\hline Lesion below & & $\mathrm{N}$ & $\%$ \\
\hline $\mathrm{C}_{5}, \mathrm{C6}$ all incomplete & & $\mathrm{I} 2$ & $13 \cdot 3$ \\
\hline $\begin{array}{l}\text { C7 (8) incomplete } \\
\text { complete }\end{array}$ & $\begin{array}{l}3 \\
2\end{array}$ & 5 & $5 \cdot 6$ \\
\hline $\begin{array}{l}\text { TI incomplete } \\
\text { complete }\end{array}$ & $\begin{array}{l}28 \\
16\end{array}$ & 44 & $48 \cdot 9$ \\
\hline Total & & 6I & $67 \cdot 8$ \\
\hline Non-drivers & & 29 & $32 \cdot 2$ \\
\hline $\begin{array}{l}\text { Due to SCI : } 6 \text { below } \mathrm{C}_{5} \\
\text { and other injuries } \\
\text { Due to older age, } \\
\text { psychiatric problems, } \\
\text { epilepsy, decrease of } \\
\text { vision or disinclination }\end{array}$ & & 17 & \\
\hline
\end{tabular}


finding a permanent partner. Serious problems, however, occurred in some married or engaged couples.

Our own experience and that of other authorities (Maury, I964; Meinecke, I964; Guttmann, I973), show that paraplegics and even tetraplegics can make satisfactory partners in marriage and that their divorce rate is not higher than in the healthy population.

Resettlement (Table VI) plays the essential part of the ultimate integration of the spinal cord injured. Vocational assistance, the co-operation of social workers, occupational therapeutists, insurances, local authorities and last, but not least, the Swiss Paraplegic Foundation enabled 80 per cent of patients to go back to their families, either in their original homes $(65.5$ per cent, 27.8 per cent with special adaptations), or in new more suitable homes ( 14.5 per cent); and 15.6 per cent of patients live apart from their families for such reasons as new jobs, study or sheer independency.

Pre-injury Education and Improvement of Education following Injury (Table VII). Over 50 per cent of SCI patients have minimal basic school education (several

\section{TABLE VI}

Resettlement

\begin{tabular}{lrr}
\hline Living conditions & N & $\%$ \\
\hline With family, in original home & & \\
$\quad$ (parents, consort, siblings, etc) & 59 & $65 \cdot 5$ \\
With family, in a new home & $\mathrm{I} 3$ & $\mathrm{I} 4 \cdot 5$ \\
With friends in a new home & 8 & $8 \cdot 9$ \\
Living alone, in a new home & 6 & $6 \cdot 7$ \\
Living in sheltered institutions & 4 & $4 \cdot 4$ \\
& 90 & \multicolumn{1}{c}{ I00 } \\
\hline
\end{tabular}

TABLE VII

Preinjury education and improvement of education following injury

\begin{tabular}{|c|c|c|c|c|}
\hline \multirow{2}{*}{ Preinjury education level } & \multirow[t]{2}{*}{$\mathrm{N}$} & \multirow[t]{2}{*}{$\%$} & \multicolumn{2}{|c|}{ Improving education } \\
\hline & & & $\mathrm{N}$ & $\%$ \\
\hline $\begin{array}{l}\text { Basic schools (8-9 yrs), } \\
\text { often with following } \\
\text { apprenticeship }\end{array}$ & 46 & $5 \mathrm{I} \cdot \mathrm{I}$ & 8 & $8 \cdot 8$ \\
\hline Basic schools + further & & & & \\
\hline professional schools & 35 & $38 \cdot 8$ & I4 & $15 \cdot 5$ \\
\hline School w. University & 6 & & & \\
\hline $\begin{array}{l}\text { entrance } \\
\text { University degree }\end{array}$ & $\begin{array}{l}6 \\
2\end{array}$ & $6 \cdot 7$ & I & $\begin{array}{ll}1 \cdot 2 \\
0\end{array}$ \\
\hline No education (imbecile) & I & $\mathrm{I} \cdot 2$ & 0 & 0 \\
\hline Total & 90 & 100 & 23 & $25 \cdot 5$ \\
\hline
\end{tabular}


with apprenticeship). Of these only 8.8 per cent subsequently improve their education.

Those patients having passed basic schools + further professional schools (38.8 per cent) represent the largest group improving their education ( 40 per cent).

Altogether 25 per cent reported that they had improved their education subsequent to their disability. The reports from other countries show higher figures (El Ghatit \& Hanson, I979, U.S.A.).

Social and financial conditions. Our examination enabled us to say that the patients' general socio-economic situation was satisfactory. The following institutions contribute to this:

(a) I.V. (National Invalidity Insurance compulsory for all the inhabitants of Switzerland), in 83 cases $(92.3$ per cent); seven foreign workers did not receive this benefit. 38 cases.

(b) Legal Insurance SUVA (Schweizerische Unfallversicherungs-Anstalt) in

(c) Indemnification Allowances in 20 instances.

(d) Military Insurance (EMV) in two cases (the best).

(e) Private Accident Insurances in I I and others.

A few cases of severe hardship have been substantially (many additionally), supported by the Swiss Paraplegic Foundation even in cases of non-membership.

In spite of the realisation that prevention is better than care we will unfortunately continue to be confronted with tetra and paraplegic patients who must be reintegrated in the best possible way.

\section{SUMMARY}

The purpose of this statistical review (based on 90 acute SCI admissions into the Swiss Paraplegic Centre, Basle in 1979), is to give, in the form of an evaluation, consideration to the social and vocational significance of the patients' disability.

Seventy patients $(77 \cdot 8$ per cent), are working or will work, (of 35 tetraplegics, 25 , of 55 paraplegics, 45$)$; and 67.8 per cent drive a car. So far as marital status is concerned there have been no significant changes as yet.

The important question of resettlement was ideally solved in 80 per cent of patients. The improvement of education following injury was in general relatively limited. Twenty-five per cent reported that they have improved their education subsequent to their disability, these coming from the group having initially more than basic education. Socio-economic conditions of our patients are satisfactory. Cases of hardship have been substantially supported by the Swiss Paraplegic Foundation.

\section{RÉSUMÉ}

Dans ce travail, nous avons analysé la réinsertion professionelle et sociale de 90 des I 8 patients, qui à la suite d'une lésion traumatique de la moelle épinière ont séjourné dans le Centre Suisse de Paraplégiques à Bàle en 1979.

Soixant-dix patients $(77.8 \%)$ travaillent actuellement, le recyclage professionnelinclu (des 35 tétraplégiques, 25 travaillent, et des 55 paraplégiques, 25); et $67 \cdot 8 \%$ conduisent de nouveau ( $48 \cdot 6 \%$ des tétraplégiques et $8 \mathbf{I} \cdot 8 \%$ des paraplégiques).

Aucun changement d'état civil significatif n'est apparu. Le problème de logement dans $80 \%$ a pu être résolu de manière très satisfaisante.

Seuls $25 \%$ des patients ont pu améliorer leur culture générale à la suite de l'accident, 
dont la plus grande proportion vient de personnes ayant une instruction plus qu'élémentaire.

La situation socio-économique de nos patients peut être considérée comme bonne. La Fondation Suisse pour Paraplégiques a pris en charge les cas en difficulté financière.

\section{ZUSAMMENFASSUNG}

In der vorliegenden Arbeit werden 90 von I I 8 Patienten, die I979 im Anschluss an eine traumatische Querschnittlähmung in das Schweizerische Paraplegikerzentrum Basel eingeliefert wurden, hinsichtlich beruflicher und sozialer Reintegration analysiert.

Siebzig Patienten $(77.8 \%$ ) arbeiten zum jetzigen Zeitpunkt wieder oder sind noch in Unschulung (Weiterbildung) begriffen (von 35 Tetraplegikern sind es 25, die arbeiten und von 55 Paraplegikern 45 ); und $67 \cdot 8 \%$ fahren (wieder) Auto $(48 \cdot 6 \%$ der Tetra- und $8 \mathrm{I} \cdot 8 \%$ der Paraplegiker).

Es traten keine relevanten Aenderungen im Zivilstand auf. Die Wohnungsprobleme konnten in $80 \%$ der Fälle ideal gelöst werden. $25 \%$ der Patienten konnten sich im Anschluss an die Querschnittlähmung bildungsmässig verbessern, wobei die höchste Verbesserungsrate bei denjenigen Patienten lag, welche ohnehin schon mehr als nur Grundschulbildung hatten.

Die Socio-ekonomische Situation kann bei unseren Patienten als im grossen und ganzen befriedigend bezeichnet werden, dank der I.V., SUVA, Haftpflicht- und anderen Versicherungen sowie der grosszügigen Unterstützung durch die Schweizerische Paraplegiker-Stiftung in Härtefällen.

\section{REFERENCES}

El Ghatit, A. Z. \& Hanson, R. W. (1979). Educational and training levels and employment of the spinal cord injured patient. Arch. Phys. Med. Rehabil., 60, 405-406.

Guttmann, L. (1964). The married life of paraplegics and tetraplegics. Paraplegia, 2, I 82-I 88 .

MaURY, M. (1964). The future of paraplegics. Results of a survey of the home conditions of the first 250 paraplegics discharged from the Centre de Ré-éducation Motrice, Fontainebleau. Paraplegia, 2, 156-157.

Meinecke, F. W. (1964). Social aspects of paraplegic coal-miners in Germany. Paraplegia, 2, I63-169. 